\title{
Working from home before, during and after the Covid-19 pandemic: implications for workers and organisations
}

\author{
NICOLA GREEN*, DAVID TAPPIN**, and TIM BENTLEY***
}

\begin{abstract}
The Covid-19 pandemic has resulted, to date, in an estimated 29 per cent of the New Zealand (NZ) workforce moving quickly from centralised work locations to full time working from home (WFH). The literature prior to these extraordinary events suggests WFH is beneficial for employee wellbeing and performance, and organisational outcomes, notably productivity, retention, and business continuity in times of disruption. Lack of organisational preparedness, technological limitations, managerial reluctance, and the potential drawbacks of social isolation have meant that the rates of regular, planned WFH as a flexible work option have traditionally been low. This paper summarises the knowledge base of benefits and limitations of WFH prior to COVID-19 and speculates how the experiences of WFH during the pandemic are likely to shape the future of WFH for workers, organisations, and employees.
\end{abstract}

Keywords: Telework, working from home, Covid-19, future of work

\section{Introduction}

The day before New Zealand (NZ) recorded its first case of the coronavirus on February 28, 2020, there was a report of "the largest mass exercise in remote working in global corporate history" (Field, 2020) as companies responded to the "stay at home' message to help control the virus. By the following week, NZ organisations were following suit (Carroll, 2020) and working from home (WFH) has continued throughout all the alert levels of the pandemic. This has stimulated interest WFH, the benefits and challenges it presents for workers and organisations, and how the experiences of WFH in a crisis will impact on WFH in the future. In the extant literature, WFH is variably termed 'telework', 'telecommuting', 'remote working', 'e-work' and 'virtual work' (Sullivan, 2003). These terms all refer to the concept of using information and communication technology (ICT) to support WFH or at a location that is removed from the physical location of the organisation (Offstein et al., 2010). Though remote work began in the US in the early 1970s (Katz, 1987), it has become more popular recently, driven by advances in ICT (e.g. broadband internet, mobile devices), workers' and organisations' desire to be flexible about where and when work takes place (Sia et al., 2004; Hilbrecht et al., 2013), environmental concerns (Mello, 2007) and the requirement for organisations to consider requests for flexible work arrangements (Eurofound \& the

\footnotetext{
* School of Management, Massey University, New Zealand.

Corresponding author: n.j.green@massey.ac.nz

** Assoc. Prof., School of Management, Massey University

*** Prof., School of Business and Law, Edith Cowan University, Western Australia
}

The authors are grateful for the useful feedback offered by the reviewers. 
International Labour Office, 2017; Employment New Zealand, 2015). In addition, pertinent to the Covid-19 context, business continuity and resilience is, or should be, a driver for WFH as benefits in both these areas are evident in the literature (Martin \& MacDonnell, 2012; Green et al., 2017). While there is a large body of literature considering antecedents and outcomes of WFH, the need to understand WFH was highlighted as thousands of workers in NZ moved quickly to this new work arrangement. This paper begins by summarising the available statistics for WFH in NZ before and during the pandemic followed by a brief review of the literature to explain the potential benefits and challenges of WFH. The paper is focused on employees rather than self-employed workers and concludes with a discussion about how the experience of WFH during Covid-19 may impact on WFH in the future.

\section{Extent of WFH: before and during the COVID-19 pandemic}

Despite the potential benefits and gradual increase in uptake, the global incidence of WFH is varied and remains generally low. Eurofound and the ILO (2017) report a range of two per cent to 40 per cent, depending on country, occupation, sector, and frequency. Before Covid19, Statistics NZ (2019a) noted that more than one-third of NZ employees had engaged in some WFH in their main job, with males and female employees fairly evenly represented. The ability to WFH varies by industry, 70 per cent reported WFH to some extent in the education sector with only 10 per cent reported in retail, trade and accommodation and food services. WFH has been most common amongst professionals and managers, and least likely for machinery operators, drivers, and labourers for obvious reasons. Though the frequency of WFH is not clear, 16 per cent of employees reported having an arrangement with their employer allowing them to work from home in 2018 (Statistics NZ, 2019b). The Trans-Tasman telework study of more than 1800 participants in 50 organisations found that 89 per cent worked away from the central work location (mostly at home) for one or more hours per week for their employer (Bentley et al., 2013). Some 35 per cent spent less than eight hours a week WFH, 38 per centspent one to three days per week and 16 per cent more than three days per week WFH (Bentley et al., 2013). This contrasts with estimates at Covid-19 alert levels three and four that 27-31 per cent of the total NZ workforce, between 727,000 and 777,000 people, were working full-time from home in an effort to control the virus (Auckland Council, 2020; Olsen, 2020). These workers usually work in the country's urban offices, and primarily in the communications and technology, financial, administrative, professional, and public services sectors.

\section{Benefits of WFH in business as usual (BAU) and during a disruption.}

Gajendran \& Harrison's (2007) meta-analysis showed that WFH is associated with higher job satisfaction and performance, lower work-family conflict, and lower turnover propensity. The proposed mechanism of these outcomes is the increase in the worker's perceived autonomy afforded by WFH. A more recent meta-analysis (Martin \& MacDonnell, 2012) found a positive relationship between WFH and organisational outcomes of productivity, retention, turnover intent, commitment, and performance. These studies both conclude that WFH is mainly a "good thing" for both individuals and organisations (Martin \& MacDonnell, 2012, p. 611). However, these outcomes come with caveats. The intensity or frequency of WFH seems to moderate the outcomes with high intensity WFH, more than two or three days per week, being associated with negative impacts on work and family relationships (Golden, 2006; Gajendran 
\& Harrison, 2007) and the blurring of the lines between the two. The relationship between these variables are complex and, as Bentley et al., (2016) found, moderated by social support. Using a NZ sample, these authors found that organisational social support (a combination of perceived social and organisational support) and support for the individual WFH (comprising of manager trust and support, and technical support) were associated with increased job satisfaction and reduced psychological strain, mediated by social isolation. However, these studies have been conducted in a BAU environment and the effects of WFH in times of crisis are less well understood. As a US Government Accountability Office (GAO) report (2011) notes, implementing WFH in a crisis is different from WFH in BAU environments.

WFH has often been promoted in the grey literature (e.g. Deloitte, 2011; Australian Institute of Management, 2012) as a way to continue operations during a disaster while the empirical evidence of this is scarce. Research by Green and colleagues (2017) and that of Donnelly \& Proctor-Thomson (2015), following the Christchurch earthquakes in 2010-2011, are exceptions. These studies found that moving to $\mathrm{WFH}$, following a natural disaster, supported business continuity and employee wellbeing, though this was moderated by personal situation and work role (Donnelly \& Proctor-Thomson, 2015), as well as IT infrastructure and resources and previous experience of WFH (Green et al. 2017). During the Covid-19 pandemic, business continuity has been evident for those businesses which could accommodate WFH, and wellbeing has been enhanced on a broader scale as WFH has facilitated social distancing and containment of the virus. Alongside the benefits of WFH, there are challenges, many of which have also been anecdotally experienced by workers and organisations during the recent crisis. A brief review of the challenges identified in the literature is now presented, along with how these may differ in the context of a crisis.

\section{Challenges of WFH in business as usual (BAU) and during a disruption}

Moving to a new way of working, either in BAU or as a response to disruption, alters both the employment and psychological contract between workers and organisations (Jaakson \& Kallaste, 2010). If organisations do not recognise the change in these dynamics, the potential effectiveness of WFH can be limited (Eckhardt et al., 2019.) Key challenges to WFH, drawn from a rapid review of the literature, are shown in Figure 1. Possible challenges of technology, working environment, communication and management are interrelated and, without attention given to these areas, WFH can have negative effects of social isolation, work-home conflict, and work intensification (e.g. Bentley et al., 2016; Eddleston \& Mulki, 2017). These, in turn, can have negative impacts on wellbeing (physical and mental health) and work performance (e.g. Eurofound \& ILO, 2017; Gajendran \& Harrison, 2007). The principle areas of challenge for WFH that are illustrated in Figure 1 are considered in more detail in the next sections. 


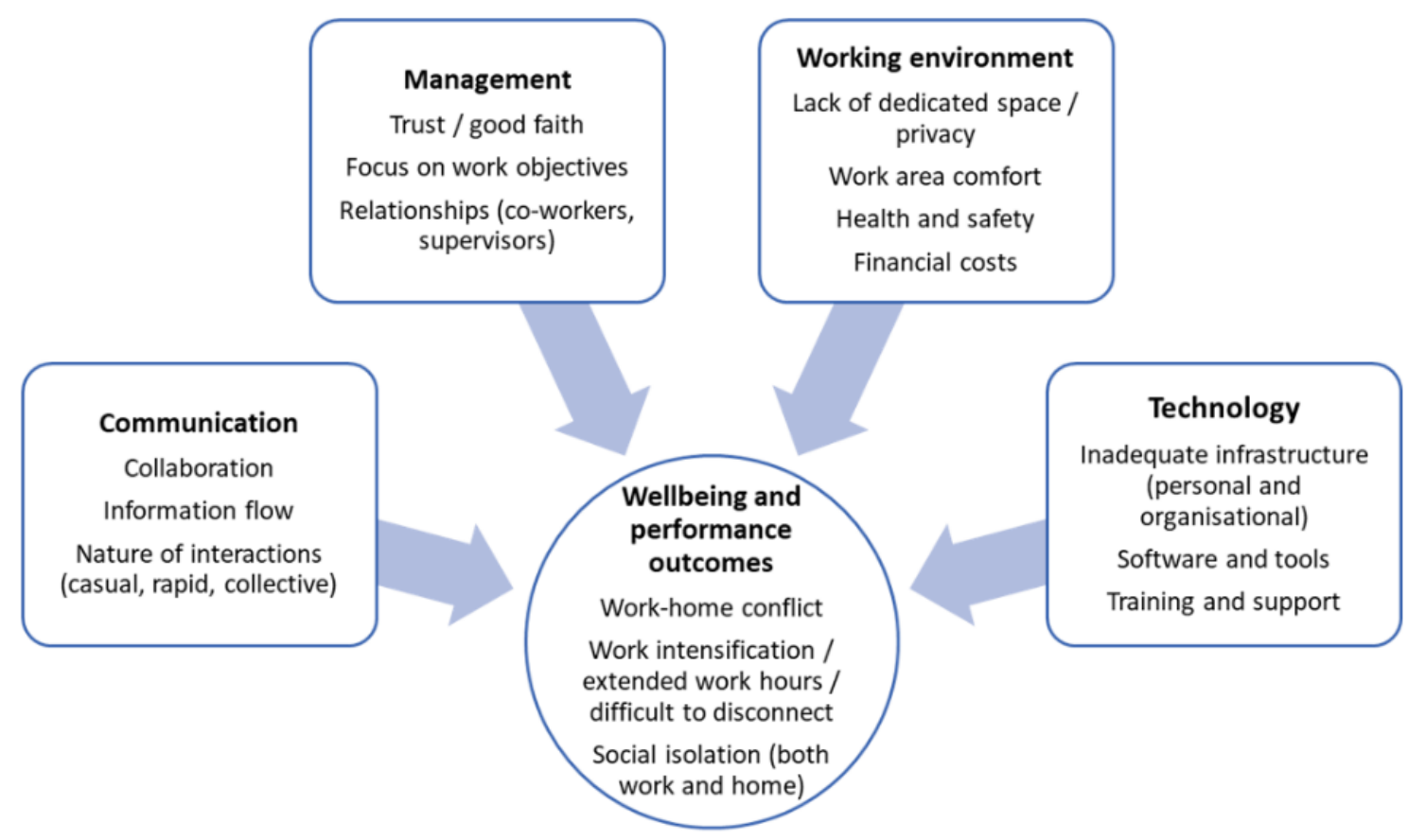

Figure 1: Key challenges of WFH (authors' compilation)

\section{Technology}

Despite technological advances, the provision of sufficient technology that is compatible and underpinned by ICT policies continues to be a challenge to WFH (Koroma et al., 2014; Green et al., 2017). Technology plays a vital role in mitigating the potential disadvantages of WFH, namely social isolation and difficulties with communication and collaboration, as discussed below. Support and training for workers using technology while WFH is also important for enabling workers to maintain their performance at work.

\section{Wellbeing and performance}

WFH can result in social and professional isolation when workers are away from the traditional social environment of work (Golden et al., 2008; Maruyama \& Tietze, 2012; Bentley et al., 2016). Social isolation has been highlighted in the Covid-19 pandemic as people were not only isolated from their work but also their friends, wider family and recreational activities. Social isolation was found to be a negative outcome of WFH after the Christchurch earthquakes (Green, 2014), even when other social interactions were still permitted. Further, Donnelly \& Proctor-Thomson (2015) reported heightened feelings of isolation due to the nature of the disaster. Bentley et al. (2016) found that social isolation is moderated by organisational social support. Technology can play a significant role in this through the use of rich communication technologies, such as videoconferencing (Eckhardt et al., 2019; Turetken et al., 2011) as we have seen during the pandemic as Zoom has become part of our vernacular. In contrast, WFH can encourage remote workers to overwork as work is always 'right there', and this can create work-family conflict (Eddleston \& Mulki, 2017), negatively impacting on wellbeing and mental health (Eurofound \& ILO, 2017). Anecdotal reports of increased work-family boundary stressors have been seen in the current pandemic, particularly in situations where parents juggle WFH while simultaneously caring for and home-schooling dependents. Remote workers who 
have strategies to segment work and family (e.g. a dedicated workspace) have been reported to have the lowest work-family conflict, at least in a BAU situation (Eddleston \& Mulki, 2017). In addition to worker behaviour, organisations need to create a culture, along with policies, that enable workers to disconnect from work. Some countries and companies are addressing this with policy responses termed 'the right to be disconnected' (Eurofound \& ILO, 2017). Moreover, a hybrid model of working some time at the office and some time at home helps to mitigate the negative risks of WFH.

Moving to a WFH work arrangement can lead to work intensification for managers. This was seen following the earthquakes in Christchurch where Donnelly \& Proctor-Thomson (2015) found significant variation in the experiences and perceptions of team leaders compared to team members, with greater demands on team leaders to control and coordinate operations and support staff in challenging circumstances, which required enhanced communication. Anecdotally, this has also been the case for some team leaders in the current pandemic disruption (personal communication).

\section{Communication and management}

Communication and collaboration can be limited by WFH (Green et al., 2017) and is an oftencited reason for organisations not to adopt WFH. Technological tools (e.g. online collaboration tools, web-based presentation rooms, workflow management tools and desktop video conferencing can be used to enhance collaboration (Bayrak, 2012; Ye, 2012). Indeed, Bosua et al., (2013) found improved communication tools and high-level ICT support correlated with greater productivity. In addition to technological tools, management and communication style influence the success of WFH. WFH is different to traditional office-based work and, thus, requires adjustment to both management and communication. The greatest barrier to successful WFH can be the mindset of management, with the traditional view of needing to see the worker and measure productivity with 'time in the seat'. Effective management in a WFH environment requires relationship-orientated behaviours with a focus on clear and frequent communication (Dahlstrom, 2013) with the goal of establishing/maintaining good faith in the employment relationship.

Communication in a WFH context must, therefore, be more explicit than it might be in a comparable in-person interaction (Makarius \& Larson, 2017). Clear work objectives with realistic goals need to be communicated through multiple channels, determined by the preferences of workers. The development of trust and perception of autonomy have also been associated with performance and satisfaction in remote workers (Gajendran et al., 2015; Kröll et al., 2017). In addition, effective communications between workers is important for information flow and coordination of work activities (Charalampous et al., 2019). Managers can help home-based workers build relationships with others by planning social events and providing means of informal communication, learning, and mentoring (Makarius \& Larson, 2017).

\section{Working environment}

The physical home working environment is often not as suitable as what is provided at a central office workplace (Bentley et al., 2013), potentially impacting negatively on a workers' physical as well as mental health. Employers as Persons Conducting a Business or Undertaking (PCBU) have health and safety obligations to workers regardless of their location, and appropriate policies and processes around this are essential (Nayani et al., 2018). In addition, if there is a 
not a private or dedicated work area within the home environment, this can impact on the privacy of the work being done as well as blurring the work and home boundaries, as discussed with respect to wellbeing and performance.

WFH can also shift operational costs (e.g. internet, equipment, heating) to the worker, and while workers can be comfortable about this when WFH is voluntary (Jaakson \& Kallaste, 2010), or short term in a crisis (Green, 2014), it is important that the implications of this on the employment relationship are considered and agreement reached with the workers. However, during disruptive events, the contextual situation impacts on operations, ICT infrastructure, personal circumstances of workers, management of employees, the voluntary nature of WFH for workers, as well as planning and policies (Green et al., 2017; Donnelly \& Proctor-Thomson, 2015). For example, following the Christchurch earthquakes, the move to WFH was unplanned and impeded by the loss of infrastructure, but WFH was not always mandatory as other facilities were available and in-person contact was possible to mitigate challenges of social isolation and communication. This contrasts with the Covid-19 situation where WFH, where possible, was mandated by the government; infrastructure was unaffected but social isolation was enforced.

The previous sections have discussed the benefits and challenges of WFH in BAU and disruptive situations. Now, drawing on the WFH literature and New Zealand's experiences of WFH in disruptive events, we discuss how WFH may look in the short and medium-term future.

\section{WFH: shaping the future}

Following a period of disruption there is typically a transition back to BAU. The duration and timing of this depends on the nature of the disruption. A transport disruption, for instance, may be of a short duration with no wider impacts on usual life. Return to 'normal' after a natural disaster may be over a longer duration and, as in the case of the Covid-19 pandemic, a return to BAU may have frequent interruptions if restrictions have to be reapplied or workers have to self-isolate in response to the threat of virus infection. Research in the post-earthquake disaster context identified the transition from teleworking to BAU to be an important phase for framing WFH in the future, contributing to organisational development and impacting on wellbeing and engagement (Donnelly \& Proctor-Thomson, 2015; Green et al. 2017).

Returning to a centralised workplace following a period of teleworking should be carefully managed in situations where there are threats to mental and physical health. The World Health Organization (2020) recognises that a return to the usual way of working may be stressful for some people. In the current situation, stress or anxiety about Covid-19 can also be accompanied by difficulties which a return to the workplace presents to managing home and family responsibilities if, for example, schools and childcare facilities are closed. On the other hand, forced WFH can pose risks of increased work-family conflict and domestic violence along with added financial stressors of the current pandemic, such as cuts to remuneration and leave entitlements. In both situations, the wellbeing implications of returning to a workplace need to be considered for staff, plans communicated effectively, and support provided. Depending on the circumstances of the disruption, the organisation and the individuals, this may need to be done in a gradual way (Green, 2014). 
After having the opportunity to experience WFH, it is likely that many workers will want this situation to continue, at least in some capacity. In a post-Christchurch earthquake study (Green et al., 2017), following a prolonged WFH experience, the desire of groups and individuals to telework more regularly did increase, however, this was only supported by some managers and in limited circumstances. Employees expressed dissatisfaction with this stance, potentially affecting engagement and retention. Yost (2012) suggests that organisations should be ready to deal with the question, "if we can WFH in a disaster, why can't we always do it?" Indeed, in NZ, early indications are that up to 90 per cent of workers in WFH-capable organisations wish to continue to WFH to some extent after the Covid-19 experience (University of Otago, 2020). If WFH is successful in response to a disaster and it is not adopted more broadly, the advantages it offers may not be realised (Green et al., 2017). In the US, where WFH for continuation of operations is legislated, the Federal Office of Personnel Management (OPM) reports that the top barrier to employees' ability to WFH were management resistance (GAO, 2017). Donnelly \& Proctor-Thomson (2015) found that, while managers' acknowledged the benefits of telework in times of crisis, they did not necessarily see WFH as a BAU work arrangement due to perceptions of the loss of connectiveness, collaboration, and in-person communication. In contrast workers, while acknowledging some communication limitations, recognised the productivity, wellness, and satisfaction benefits of hybrid teleworking.

WFH as an alternative working arrangement can be viewed as an organisational and human resource innovation (Lee et al., 2009). Its introduction involves adjustment of the organisation in terms of its governance structure, coordination and control mechanisms, relationships and reward systems (Martínez-Sánchez et al., 2008; Sia et al., 2004; Watad \& Will, 2003). Conversely, adoption of WFH can be triggered by organisational change and become imbedded when WFH practices become more effective than existing practices (Daniels et al., 2001). If WFH is implemented rapidly without planning, there is limited ability for adjustment of structural elements, such as policies and procedures and in the Covid-19 context, it was an immediate change to high intensity WFH. Thus, if managerial attitudes about telework were formed from this disorganised state, and then carried through to a BAU environment, the potential benefits of telework may go unrealised (Green, et al., 2017). The change to WFH forced by Covid-19 can, therefore, be used as an opportunity to spark innovation and development to enhance organisational capabilities. One of the case studies reported in Green et al. (2017) recognised the limitations of their existing ICT systems for WFH during their disaster experience, and established a virtual platform and added collaboration and communication tools to be used in BAU. Another organisation, seeing the valuable role WFH played in business continuity in a disaster, expanded the roles that could be teleworked, improved its IT infrastructure and remote connection capabilities. In addition, the experiences of WFH in a disruptive event can help with integrating WFH into continuity planning in a more effective way and setting clear expectations and management guidelines for WFH for subsequent disruptive events (Donnelly \& Proctor-Thomson, 2015). Moreover, the forced WFH experiences provide an opportunity for organisations to evaluate, design and formalise sustainable WFH arrangements in BAU. Broader community and societal innovation can also stem from crisis experiences, Levine (2017) reports that the City of Calgary used its natural disaster experiences as a strategic driver for WFH to develop a flexible working hub and a WFH programme.

It is also important to recognise that a large-scale change in the way people work has implications, both potentially positive and negative for the wider society. For example, fewer travelling to work has positive implications for the environment and traffic congestion (Mello, 2007, Siha \& Monroe, 2006), and may save on capital costs associated with fixed office spaces 
(Atkyns et al., 2002; Mello, 2007). However, WFH also changes where the population lives and works but has ramifications for infrastructure and urban planning (Alizadeh, 2013), and may have negative consequences for central city areas.

\section{Conclusions}

The onset and rapid development of the Covid-19 pandemic in early 2020 has renewed interest in WFH as millions of people are forced to socially isolate to control the spread of the virus. The extant literature suggests that WFH can be beneficial for job satisfaction, performance, retention and managing work-family commitments. Additionally, in times of disruption WFH has a positive effect on business continuity. However, the outcomes of WFH are influenced by the frequency of time spent away from the central workplace and social and organisational support. Moreover, to be successful, attention needs to be paid to technological needs, working environments, communication, and management styles. The openness of organisational leaders to explore, support and adjust to alternative ways of working is a significant factor for the successful adoption of WFH arrangements. With the Covid-19 pandemic, WFH has had to be used and this 'enforced experiment' offers a significant learning opportunity for organisations to evaluate what 'worked' and what did not, and in what ways WFH could be best managed to benefit both workers and organisations. In addition, this forced trial provides an opportunity to design robust WFH practices for BAU and in times of disruption. As is now evident with other jurisdictions and in NZ, the effects of the pandemic vary over time, and WFH is now required again. The research from past events suggests that the uptake of WFH in BAU following a crisis is low, with organisations simply reverting to previous behaviours. Consequently, organisations may miss out on opportunities for positive adaptation and innovation. As the pandemic continues worldwide, it remains to be seen if organisations are open to embedding new ways of working as BAU, making informed, and evidence-based decisions or simply retreating to old ways of working based on a personal worldviews.

\section{References}

Alizadeh, T. (2013) Planning implications of telework: a policy analysis of the Sydney metropolitan strategy. Australian Planner, 50(4), 304-315

Atkyns, R., Blazek, M., \& Roitz, J. (2002) Measurement of environmental impacts of telework adoption amidst change in complex organizations: AT\&T survey methodology and results. Resources Conservation and Recycling, 36(3), 267-285

Auckland Council. (2020). Auckland Economic Update. https://knowledgeauckland.org.nz/media/1802/04april-2020-covid-19-economicupdate-2-groups-in-lockdown-employment.pdf

Australian Institute of Management. (2012). Managing in a Flexible Work Environment. https://www.wgea.gov.au/sites/default/files/documents/AIM-Managing-in-a-FlexibleWork-Environment.pdf

Bayrak, T. (2012). IT support services for telecommuting workforce. Telematics and Informatics, 29(3), 286-293 
Bentley, T., McLeod, L., Bosua, R., Teo, S., Rasmussen, E., \& Tan, F. (2013). The TransTasman Telework Survey. A Future of Work Programme Project Report. New Zealand Work Institute. https://workresearch.aut.ac.nz/_data/assets/pdf_file/0018/34209/trans-tasmantelework-survey-report-Final-December-2013.pdf

Bentley, T. A., Teo, S. T. T., McLeod, L., Tan, F., Bosua, R., \& Gloet, M. (2016). The role of organisational support in teleworker wellbeing: A socio-technical systems approach. Applied Ergonomics, 52, 207-215

Bosua, R., Gloet, M., Kurnia, S., Mendoza, A., \& Yong, J. (2013). Telework, productivity and wellbeing: an Australian perspective. Telecommunications Journal of Australia, 63(1), $1-12$

Carroll, M. (2020, March 4). NZ employees keen to join the coronavirus office exodus and work from home. https://www.stuff.co.nz/business/industries/119994921/nz-employeeskeen-to-join-the-coronavirus-office-exodus-and-work-from-home

Charalampous, M., Grant, C.A., Tramontano, C., \& Michailidis, E. (2019). Systematically reviewing remote e-workers well-being at work: a multidimensional approach. European Journal of Work and Organizational, 28(1), 51-73

Dahlstrom, T.R. (2013). Telecommuting and leadership style, Public Personnel Management, $42(3) 438-451$

Daniels, K., Lamond, D., \& Standen, P. (2001). Teleworking: frameworks for organizational research. Journal of Management Studies, 38(8), 1151-1185.

Deloitte. (2011). Next Generation Telework: A Literature Review, Report by Deloitte Access Economics for Department of Broadband, Communications and the Digital Economy. https://melbourneinstitute.unimelb.edu.au/assets/documents/hilda-bibliography/otherpublications/2011/Next_Generation_Telework-A_Literature_Review-July_2011.pdf

Donnelly N. \& Proctor-Thomson S.B. (2015) Disrupted work: Home-based teleworking (HbTW) in the aftermath of a natural disaster, New Technology, Work and Employment, $30(1), 47-61$

Eckhardt, A., Endter, F., Giordano, A. \& Somers, P. (2019). Three Stages to a Virtual Workforce, MIS Quarterly Executive, 18(1) 19-35

Eddleston, K.A. \& Mulki, J. (2017) Toward Understanding Remote Workers' Management of Work-Family Boundaries: The Complexity of Workplace Embeddedness, Group \& Organization Management, 42(3), 346-387

Employment New Zealand. (2015). Flexible Working Arrangements Guide: A guide for employees and employers (ER-009 08/15). https://www.employment.govt.nz/assets/Uploads/tools-andresources/publications/0d0258f22f/flexible-working-arrangement-guide.pdf 
Eurofound and the International Labour Office (2017) Working anytime, anywhere: The effects on the world of work, Publications Office of the European Union, Luxembourg, and the International Labour Office, Geneva. https://www.eurofound.europa.eu/sites/default/files/ef_publication/field_ef_document lef1658en.pdf

Field, M. (2020, February 27). Working from home is now a corporate weapon to beat coronavirus. https://www.stuff.co.nz/business/world/119841672/working-from-homeis-now-a-corporate-weapon-to-beat-coronavirus

GAO. (2011). Agencies needs coordinated guidance on incorporating telework into emergency and continuity planning (GAO-11-628). https://www.gao.gov/products/GAO-11-628

GAO. (2017). Additional controls could strengthen telework program compliance and data reporiting (GAO-17-247).https://www.gao.gov/products/GAO-17-247

Gajendran, R. S., \& Harrison, D. A. (2007). The Good, the Bad, and the Unknown About Telecommuting: Meta-Analysis of Psychological Mediators and Individual Consequences. Journal of Applied Psychology, 92(6), 1524-1541.

Gajendran, R. S., Harrison, D. A., \& Delaney-Klinger, K. (2015) Are telecommuters remotely good citizens? Unpacking telecommuting's effects on performance via ideals and job resources, Personnel Psychology, 68(2), 353-393.

Golden, T. (2006). The role of relationships in understanding telecommuter satisfaction. Journal of Organizational Behavior, 27(3), 319-340.

Golden, T., Veiga, J. F., \& Dino, R. N. (2008). The impact of professional isolation on teleworker job performance and turnover intentions: Does time spent teleworking, interacting face-to- face, or having access to communication-enhancing technology matter? Journal of Applied Psychology, 93(6), 1412-1421.

Green, N. J. (2014). A multi-level analysis of telework adoptions and outcomes following a natural disaster: the experience of two Christchurch organisations [Unpublished master's thesis]. AUT University

Green, N., Tappin, D. \& Bentley, T. (2017). Exploring the teleworking experiences of organisations in a post-disaster environment, New Zealand Journal of Human Resources Management, 17(1), 1-19

Hilbrecht, M., Shaw, S. M., Johnson, L. C., \& Andrey, J. (2013). Remixing work, family and leisure: teleworkers' experiences of everyday life. New Technology, Work and Employment, 28(2), 130-144.

Olsen, B. (2020). COVID-19 lockdown sees half of kiwi workers sitting idle at home. Informetrics. https://www.infometrics.co.nz/COVID-19-lockdown-sees-half-of-kiwiworkers-sitting-idle-at-home

Jaakson,K. \& Kallaste, E. (2010). Beyond flexibility: reallocation of responsibilities in the case of telework, New Technology, Work and Employment, 25, 196-209. 
Katz, A. I. (1987). The management, control, and evaluation of a telecommuting project: A case study. Information and Management, 13(4), 179-190.

Koroma, J., Hyrkkänen, U. \& Vartiainen, M. (2014). Looking for people, places and connections: Hindrances when working in multiple locations: A review. New Technology, Work and Employment, 29(2) 139-159

Kröll, C., Doebler, P. \& Nüesch, S. (2017). Meta-analytic evidence of the effectiveness of stress management at work. European Journal of Work and Organizational Psychology, 26(5), 677-693.

Lee, Y.-C., Chu, P.-Y., \& Tseng, H.-L. (2009). Exploring the relationships between information technology adoption and business process reengineering. Journal of Management and Organization, 15(2), 170-185

Levine, D.C. (2017). 5 ways remote working is impacting business resilience. FMLink. https://fmlink.com/articles/5-ways-remote-working-impacting-business-resilience/

Makarius, E., \& Larson, B. (2017). Changing the perspective of virtual work: building virtual intelligence at the individual level. The Academy of Management Perspectives, 31(2), $159-178$

Martin, B. H., \& MacDonnell, R. (2012). Is telework effective for organizations? A metaanalysis of empirical research on perceptions of telework and organizational outcomes. Management Research Review, 35(7), 602-616.

Martínez-Sánchez, A., Pérez-Pérez, M., Vela-Jiménez, M. J., \& De-Luis-Carnicer, P. (2008). Telework adoption, change management, and firm performance. Journal of Organizational Change Management, 21(1), 7-31.

Maruyama, T., \& Tietze, S. (2012). From anxiety to assurance: concerns and outcomes of telework. Personnel Review, 41(4), 450-469.

Mello, J. A. (2007). Managing Telework Programs Effectively. Employee Responsibilities and Rights Journal, 19(4), 247.

Nayani, R. J., Nielsen, K., Daniels, K., Donaldson-Feilder, E. J., \& Lewis, R. C. (2018) Out of sight and out of mind? A literature review of occupational safety and health leadership and management of distributed workers, Work and Stress, 32(2), 124-146

Offstein, E. H., Morwick, J. M., \& Koskinen, L. (2010). Making telework work: leading people and leveraging technology for competitive advantage. Strategic HR Review, 9(2), 3237.

Sia, C.-L., Teo, H.-H., Bernard C. Y., T., \& Wei, K.-K. (2004). Effects of Environmental Uncertainty on Organizational Intention to Adopt Distributed Work Arrangements. IEEE Transactions on Engineering Management, 51(3), 253-267. 
Siha, S. M., \& Monroe, R. W. (2006). Telecommuting's past and future: a literature review and research agenda. Business Process Management Journal, 12(4), 455-482

Statistics New Zealand (2019a) Over half of employees in New Zealand have flexible work hours. https://www.stats.govt.nz/news/over-half-of-employees-in-new-zealand-have$\underline{\text { flexible-work-hours }}$

Statistics New Zealand (2019b) Survey of working life: 2018. https://www.stats.govt.nz/reports/survey-of-working-life-2018

Sullivan, C. (2003). What's in a name? Definitions and conceptualisations of teleworking and homeworking. New Technology, Work and Employment, 18(3), 158-165

Turetken, O., Jain, A., Quesenberry, B., \& Ngwenyama, O. (2011). An empirical investigation of the impact of individual and work characteristics on telecommuting success. IEEE Transactions on Professional Communication, 54(1), 56-67.

University of Otago. (2020). Study investigates New Zealanders' attitudes towards working from home. https://www.otago.ac.nz/news/news/otago737417.html

Watad, M. M., \& Will, P. C. (2003). Telecommuting and organizational change: A middlemanagers' perspective. Business Process Management Journal, 9(4), 459-472.

World Health Organization. (2020). Coronavirus disease 2019 (COVID-19) Situation Report - 65. https://www.who.int/emergencies/diseases/novel-coronavirus-2019/situation$\underline{\text { reports }}$

Ye, L. R. (2012). Telecommuting: Implementation for Success. International Journal of Business \& Social Science, 3(15), 20-29.

Yost, C. W. (2012) 8 steps to make telework and flexible hours part of your disaster-response plan. FastCompany. https://www.fastcompany.com/3003392/8-steps-make-teleworkand-flexible-hours-part-your-disaster-response-plan 